\title{
Estrogen Receptor Positive by Immunohistochemistry 21-30 Percent
}

National Cancer Institute

\section{Source}

National Cancer Institute. Estrogen Receptor Positive by Immunohistochemistry 21-30

Percent. NCl Thesaurus. Code C141469.

An immunohistochemical staining finding indicating that 21-30 percent of the cells in a

tissue sample are expressing estrogen receptor. 